\title{
Diversity, bioactivity and drug development of cultivable actinobacteria in six species of bird feces
}

\author{
Xiu Chen ${ }^{1}$, Shumei Qiu ${ }^{3}$, Yi Jiang ${ }^{1, ~ *}$, Li Han², Xueshi Huang ${ }^{2}$, Chenglin Jiang ${ }^{1}$ \\ ${ }^{1}$ Yunnan Institute of Microbiology, Yunnan University, 650091 Kunming, Yunnan, P. R. China \\ ${ }^{2}$ Institute of Microbial pharmaceuticals, College of Life and Health Science, Northeastern University, 110819 Shenyang, P. R. China \\ ${ }^{3}$ Yunnan Wild Animal Park, 650218 Kunming, Yunnan, China
}

\section{Email address:}

jiangyi@ynu.edu.cn (Yi Jiang)

\section{To cite this article:}

Xiu Chen, Shumei Qiu, Yi Jiang, Li Han, Xueshi Huang, Chenglin Jiang. Diversity, Bioactivity and Drug Development of Cultivable Actinobacteria in Six Species of Bird Feces. American Journal of Bioscience. Vol. 2, No. 1, 2014, pp. 13-18.

doi: 10.11648/j.ajbio.20140201.13

\begin{abstract}
In order to provide new lead compounds of drugs and other useful products, the diversity and some bioactivities of cultivable actinobacteria in bird feces were studied. Six species of bird fecal samples were collected from Yunnan Wild Animal Park and bank of Dian Lake. The pure cultures of actinobacteria were isolated from these samples by using 6 different media. The partial 16S rRNA gene sequences of 207 selected strains were determined, the phylogenetic analysis was carried out, and antimicrobial activities were determined by using agar diffusion method. The key biosynthase genes (CYP, AHBA and SAL) of antibiotics were also detected. Total 28 genera of actinobacteria from all the samples were identified. 18 genera were identified from Pavo cristatus feces, and the actinomycete community was the most complex. These actinobacteria had wide inhibition against 10 test microbes. In 30, 25, and 36 strains of actinobacteria isolated from Pavo cristatus, Grus japonensis and Larus ridibundus feces respectively, average $22.2 \%, 8.9 \%$ and $40.8 \%$ strains had the key biosynthase genes encoding CYP, AHBA and SAL. More than 30 bioactive secondary metabolites from several actinomycete strains of bird feces were isolated and characterized. The study shows that birds fecal actinobacteria are a new potential source for discovering new drugs and other industry products.
\end{abstract}

Keywords: Bird feces, Actinobacteria, Diversity, Bioactivity

\section{Introduction}

Success rate of synthetic compounds developing into drug has been only $0.005 \%$, the rate of all natural product has been $0.6 \%$, while the rate of microbial natural product has been $1.6 \%$ according to the latest statistics in 2012 [1]. Actinobacteria were one of microorganisms producing the most antibiotics and other drugs. Most of applying antibiotics in clinic and agriculture are produced by actinobacteria now.

In order to open up new sources of actinobacteria for discovery of novel leader of drug, some mammal fecal actinobacteria were studied in our laboratory, and showed good prospects [2-3]. In this study, actinobacteria in 6 species of bird feces were isolated and identified, and some of the purified isolates were screened by using designed primers of key biosynthase genes of 3 groups antibiotics.

\section{Material and Methods}

\subsection{Sample Collection and Pretreatment}

Fresh fecal samples of 5 species of birds were collected from Yunnan Wild Animal Park, Kunming, Yunnan, China, and put instantly in septic bags, Nov 2012. Fresh feces of Larus ridibundus were collected from side of Dian Lake, Kunming. Larus ridibundus, one of typical migrants, was living in Siberia, Russia. Over thirty thousands of Larus ridibundus come to Dian Lake, Kunming, from December to next March every year for passing winter. Every sample was mixed by 3 to 8 health individuals of the same species respectively. $2 \mathrm{~g}$ of every samples were put in sterile plate, and dry naturally at $28{ }^{\circ} \mathrm{C}$ for 10 days. The dried samples were pre-treated at $80^{\circ} \mathrm{C}$ for 1 hour. A brief introduction for the 6 species of bird which belong to 6 different orders respectively is summarized in Table 1 . 
Table 1. A brief introduction for the 6 species of bird

\begin{tabular}{llll}
\hline Species names of birds & Order & Protection class in China* & List of international organization* \\
\hline Larus ridibundus & Ciconiiformes & LPW & IUCN ver 3.1 \\
Pavo cristatus & Galliformes & I & IUCN, CITES \\
Aceros undulatus & Coraciiformes & II & $/$ \\
Grus japonensis & Gruiformes & I & IUCN, CITES \\
Cygnus cygnus & Anseriformes & $/$ & UNCNCM \\
Struthio camelus & Struthionformes & $/$ & IUCN ver 3.1 \\
\hline
\end{tabular}

* LPW $=$ The Law on the Protection of the Wildlife of the People's Republic of China;

IUCN=World Conservation Union; International Union for Conservation of Nature and Natural Resources; CITES $=$ Convention on International Trade of Endangered Species;

UNCNCM=United Nations Convention on the Nature Conservancy in Munich.

\subsection{Isolation of Actinobacteria}

The pretreated samples were respectively put in $18 \mathrm{ml}$ sterile water with $0.1 \% \mathrm{Na}_{4} \mathrm{P}_{2} \mathrm{O}_{5}$, shaken for 1 hour at 180 rpm and treated by $160 \mathrm{w}$ ultrasonic for $40 \mathrm{~s}$. The suspension was diluted from $10^{-1}$ to $10^{-7}, 200 \mathrm{ul}$ of the last 3 suspensions were used for spreading onto plates respectively, and incubated at $28{ }^{\circ} \mathrm{C}$ for 10 to 30 days. Single colonies were transferred to the same medium, and incubated at $28^{\circ} \mathrm{C}$ for 7 days. The purified strains were preserved in $20 \%$ glycerol at $-20^{\circ} \mathrm{C}$. The isolation media are shown in Table 2 .

Table 2. The isolation media for actinobacteria.

\begin{tabular}{|c|c|c|}
\hline Media & Composition (content /L) * & $\mathbf{p H}$ \\
\hline YIM 171 & $\begin{array}{l}\text { Glycerol } 10 \mathrm{~g} \text {, asparagine } 1 \mathrm{~g}, \mathrm{~K}_{2} \mathrm{HPO}_{4} \cdot \mathrm{H}_{2} \mathrm{O} 1 \mathrm{~g}, \mathrm{MgSO}_{4} \cdot 7 \mathrm{H}_{2} \mathrm{O} 0.5 \mathrm{~g}, \mathrm{CaCO}_{3} 0.3 \mathrm{~g} \text {, Vit mixture } 3.7 \mathrm{mg} \text { [4], Trace salts } 1 \mathrm{~mL} \text {, } \\
\text { Potassium dichromate } 50 \mathrm{mg} \text {, or Nystatin } 50 \mathrm{mg} \text {,nalidixic acid } 25 \mathrm{mg} \text { and sodium penicillin } 5 \mathrm{mg} \text {, agar } 13 \mathrm{~g} \text {. }\end{array}$ & $7.7-8.0$ \\
\hline YIM 212 & $\begin{array}{l}\text { mycose } 5 \mathrm{~g} \text {, proline } 1 \mathrm{~g},\left(\mathrm{NH}_{4}\right)_{2} \mathrm{SO}_{4} \quad 1 \mathrm{~g}, \quad \mathrm{NaCl} \quad 1 \mathrm{~g}, \mathrm{CaCl}_{2} \quad 2 \mathrm{~g}, \quad \mathrm{~K}_{2} \mathrm{HPO}_{4} \quad 1 \mathrm{~g}, \quad \mathrm{MgSO}_{4} \cdot 7 \mathrm{H}_{2} \mathrm{O} \quad 1 \mathrm{~g}, \text { Vit mixture } 3.7 \mathrm{mg} \text {, } \\
\text { Potassium dichromate } 50 \mathrm{mg} \text {, or Nystatin } 50 \mathrm{mg} \text {,nalidixic acid } 25 \mathrm{mg} \text { and sodium penicillin } 5 \mathrm{mg} \text {, agar } 13 \mathrm{~g} \text {. }\end{array}$ & $7.0-7.2$ \\
\hline YIM 704 & $\begin{array}{l}\text { Humic acid } 1.0 \mathrm{~g}(10 \mathrm{ml} 0.2 \mathrm{~N} \mathrm{NaOH}) \text {, proline } 1 \mathrm{~g}, \mathrm{NaCl} 2 \mathrm{~g}, \mathrm{KCl} 2 \mathrm{~g}, \mathrm{MgCl}_{2} \cdot 6 \mathrm{H}_{2} \mathrm{O} 2 \mathrm{~g}, \mathrm{~K}_{2} \mathrm{HPO}_{4} 1 \mathrm{~g}, \mathrm{KNO}_{3} 0.2 \mathrm{~g}, \mathrm{CaCO}_{3} \\
0.2 \mathrm{~g}, \mathrm{FeSO}_{4} 0.01 \mathrm{~g} \text {, Vit mixture } 3.7 \mathrm{mg} \text {, Potassium dichromate } 50 \mathrm{mg} \text { or Nystatin } 50 \mathrm{mg} \text {,nalidixic acid } 25 \mathrm{mg} \text { and sodium } \\
\text { penicillin } 5 \mathrm{mg} \text {, agar } 13 \mathrm{~g} \text {. }\end{array}$ & 7.4-7.6 \\
\hline M4 & $\begin{array}{l}\text { Xylitol 1g, }\left(\mathrm{NH}_{4}\right)_{2} \mathrm{SO}_{4} 2.64 \mathrm{~g}, \mathrm{KH}_{2} \mathrm{PO}_{4} 2.38 \mathrm{~g}, \mathrm{~K}_{2} \mathrm{HPO}_{4} 5.65 \mathrm{~g}, \mathrm{MgSO}_{4} \cdot 7 \mathrm{H}_{2} \mathrm{O} 1 \mathrm{~g}, \mathrm{CuSO}_{4} \cdot 5 \mathrm{H}_{2} \mathrm{O} 0.0064 \mathrm{~g}, \mathrm{FeSO}_{4} \cdot 7 \mathrm{H}_{2} \mathrm{O} \\
0.0011 \mathrm{~g}, \mathrm{MnCl}_{2} \cdot 4 \mathrm{H}_{2} \mathrm{O} 0.0079 \mathrm{~g}, \mathrm{ZnSO}_{4} \cdot 7 \mathrm{H}_{2} \mathrm{O} 0.0015 \mathrm{~g} \text {, Nystatin } 50 \mathrm{mg} \text { and nalidixic acid } 25 \mathrm{mg} \text {, agar } 13 \mathrm{~g} \text {. }\end{array}$ & 7.0-7.2 \\
\hline M5 & The same as M4 except using Xylan 1g instead of Xylitol 1g & $7.0-7.2$ \\
\hline M6 & The same as M4 except using Lignin $1 \mathrm{~g}$ instead of Xylitol $1 \mathrm{~g}$ & $7.0-7.2$ \\
\hline
\end{tabular}

* Each medium should add $1000 \mathrm{ml}$ water

\subsection{Preservation and Classification of the Actinobacteria}

Genomic DNA of cell mass of 177 purified actinobacteria was extracted. Isolation of chromosomal DNA, PCR amplification and direct sequencing of the purified products were carried out as described approaches by Cui [5]. The partial 16S rRNA gene sequences were aligned with sequences collected from EzBioCloud using BLAST (http://eztaxon-e.ezbiocloud.net/) [6]. Phylogenetic trees were constructed by using the neighbor-joining method based on the closest sequences of the strains isolated mostly. The taxonomic state of all strains was identified to genus level.

\subsection{Determination of Antimicrobial Activities}

Antimicrobial activities of 177 purified actinobacteria from 3 species of bird feces were determined by using agar diffusion method.

\subsection{Detection of Key Biosynthase Gene of 3 Group Antibiotics}

Key biosynthase genes for three biocative metabolites of 177 purified strains were detected by PCR amplification. Gene encoding cytochrome P450 hydroxylase (CYP) genes, represent the biosynthetic enzyme gene clusters for polyene antibiotics [7]. AHBA represent the produce of key biosynthase genes of 3-amino-5-hydroxybenzoic acid for biosynthesis of antibiotics with Ansa Rings etc. [8]. SAL represent the product of epoxidase genes of salinomycin [9]. Purified genomic DNA of every strain was amplified using CYP encoding gene specific primer 1R: 5' -TGG ATC GGC GAC GAC CGS VYC GT- 3', primer 1F: 5' -CCG WAS AGS AYS CCG TCG TAC TT- 3'; AHBA primer 2R: 5' -AGA GGA TCC TTC GAG CRS GAG TTC GC- 3', primer 2F: 5' -GCA GGA TCC GGA MCA TSG CCA TGT AG- 3'; SAL encoding gene specific primer 3R: 5' -AAC GCA CGC CGT CGT TCT C- 3', primer 3F: 5' -ACC AGC CAC TTG 
CCG TCC TC- 3', respectively. The positive strips were recorded. Some DNA of the gels with positive strips was extracted and cloned, and the full genes of CYP, ABHA and SAL of positive strains were sequenced, and aligned with sequences from GenBank using BLAST (http://blast.ncbi.nlm.nih.gov/Blast.cgi) for further confirmative identity.

\section{Results}

\subsection{Selective Isolation for Fecal Actinobacteria}

Existence of Gram negative bacteria in a large number in animal feces is a main problem for isolation of actinobacteria. In order to eliminate the trouble of Gram negative bacteria and fungi, and obtaining much more un-known actinobacteria, some key points for selective isolation of actinobacteria are following as, based on the results of this test: fresh feces samples was dried at $25-28^{\circ} \mathrm{C}$ for 7 to 10 days; pre-treatments of dried samples at $80^{\circ} \mathrm{C}$ for
$60 \mathrm{~min}$ had been carried out before isolation; nystatin $50 \mathrm{mg}$, nalidixic acid $25 \mathrm{mg}$ and $5 \mathrm{mg}$ penicillin for $1000 \mathrm{ml}$ medium has to be added in the isolation medium for inhibiting fungi and Gram negative bacteria; in general the dilution of samples should be $10^{-5}$ and $10^{-6}$; YIM 171, YIM 212, and YIM 704 media were better for selective isolation of actinobacteria from fecal samples. One week was enough for their growth.

Total 472 pure cultivated strains of actinobacteria were isolated. 177 strains of them were selected after throwing out the duplicates strains based on morphological and cultural characteristics.

\subsection{Composition of Fecal Actinobacteria}

16S rRNA gene sequences of 207 selected strains were determined; the phylogenetic analysis was carried out. Total 28 genera of actinobacteria from the 6 bird feces were identified. The composition of cultivable actinobacteria in the 6 species of bird feces were showed in Table 3 and Fig. 1.

Table 3. Distribution of different genera in the 6 species of animal feces

\begin{tabular}{|c|c|c|c|c|c|c|c|c|c|c|c|c|c|}
\hline Genus & $1 *$ & 2 & 3 & 4 & 5 & 6 & Genus & 1 & 2 & 3 & 4 & 5 & 6 \\
\hline Arthrobacter & $\sqrt{ }$ & $\sqrt{ }$ & $\sqrt{ }$ & $\sqrt{ }$ & & $\sqrt{ }$ & Mycobacterium & & & & $\sqrt{ }$ & & \\
\hline Blastococcus & $\sqrt{ }$ & & & $\sqrt{ }$ & & & Nocardia & & & $\sqrt{ }$ & $\sqrt{ }$ & & \\
\hline Brevibacterium & & $\sqrt{ }$ & & & & & Nocardiopsis & & $\sqrt{ }$ & & & & \\
\hline Cellulosimicrobium & & $\sqrt{ }$ & & $\sqrt{ }$ & $\sqrt{ }$ & & Oerskovia & $\sqrt{ }$ & $\sqrt{ }$ & & & & $\sqrt{ }$ \\
\hline Corynebacterium & & & $\sqrt{ }$ & & & & Plantibacter & $\sqrt{ }$ & & & & & \\
\hline Curtobacterium & & $\sqrt{ }$ & & & & & Promicromonospora & $\sqrt{ }$ & & & & & \\
\hline Dietzia & & $\sqrt{ }$ & $\sqrt{ }$ & & & & Pseudoclavibacter & $\sqrt{ }$ & & & & & \\
\hline Gordonia & & $\sqrt{ }$ & $\sqrt{ }$ & & & & Pseudonocardia & & $\sqrt{ }$ & & & & \\
\hline Isoptericola & & $\sqrt{ }$ & & & & & Rhodococcus & & $\sqrt{ }$ & $\sqrt{ }$ & $\sqrt{ }$ & $\sqrt{ }$ & $\sqrt{ }$ \\
\hline Janibacter & & $\sqrt{ }$ & & & & & Sanguibacter & & $\sqrt{ }$ & & & & \\
\hline Kineococcus & & $\sqrt{ }$ & & & & & Streptomyces & $\sqrt{ }$ & $\sqrt{ }$ & $\sqrt{ }$ & $\sqrt{ }$ & $\sqrt{ }$ & $\sqrt{ }$ \\
\hline Kocuria & & $\sqrt{ }$ & & & & & Verrucosispora & & & & & $\sqrt{ }$ & \\
\hline Leucobacter & & $\sqrt{ }$ & & & & & Yaniella & & & $\sqrt{ }$ & $\sqrt{ }$ & & \\
\hline Microbacterium & $\sqrt{ }$ & $\sqrt{ }$ & & $\sqrt{ }$ & & & & & & & & & \\
\hline Micromonospora & & & & & $\sqrt{ }$ & & Total & 8 & 18 & 8 & 9 & 5 & 4 \\
\hline
\end{tabular}

$1 *=$ Larus ridibundus; $2=$ Pavo cristatus; $3=$ Aceros undulates; $4=$ Grus japonensis; $5=$ Anas Cygnus; $6=$ Sttruthio camelus. $\sqrt{ }=$ having

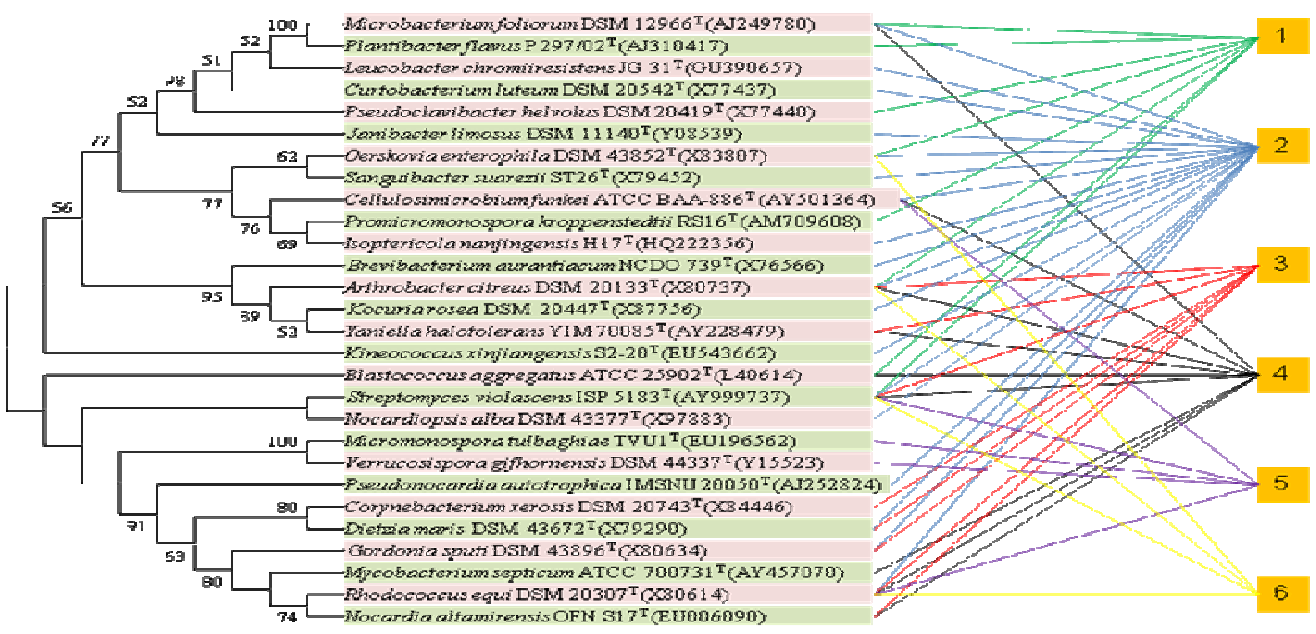

Figure 1. Neighbour-joining Phylogenetic tree were constructed based on the most closed strain in its genus. The Black fonts represent actinobacteria that have been reported animal-related. $1=$ Larus ridibundus (green lines), $2=$ Pavo cristatus (blue lines), $3=$ Aceros undulates (red lines), $4=$ Grus japonensis (black lines), $5=$ Anas Cygnus (puple lines), $6=$ Sttruthio camelus (yellow lines). 
Table 3 and Fig. 1 summarized fecal actinobacterium community of the 6 species of bird feces. Total 28 genera of actinobacteria were isolated and identified. The 28 genera belong to eight orders and sixteen families of the class Actinobacteria. Members of order Micrococcales included six families, Brevibacteriaceae, Micrococcuaceae, Sanguibactersceae, Micromonosporaceae, Microbacteraceae and Cellulomonadaceae, and 12 genera. Members of order Corynebacteriales included 4 families, Mycobacteriaceae, Corynebacteriaceae, Dietziaceae and Nocardiaceae, and 6 genera. The actinobacterium communities were different in each bird feces. Members of 18 genera of actinobacteria were isolated and identified in feces of Pavo cristatus, and was the most complex diversity in the 6 species. Only 4 genera were identified in feces of Sttruthio camelus. Members of Streptomyces were the first preponderant microbe, $\mathrm{cfu} / \mathrm{g}$ of dried samples were up to $10^{7}$ to $10^{9}$, and distributed in all 6 species of bird feces. Arthrobacter and Rhodococcus were identified in 5 species of birds. Cellulosimicrobium, Microbacterium and Oerskovia were identified in 3 species of animals. Sixteen genera, Brevibacterium, Corynebacterium, Curtobacterium, Isoptericola, Janibacter, Kineococcus, Kocuria, Leucobacter, Micromonospora, Mycobacterium, Nocardiopsis, Plantibacter, Promicromonospora, Pseudinocardia, Sanguibacter and Verrucosipora were identified only in one species of bird feces. Micromonospora, Nocardiopsis and Pseudinocardia of them were common in soil, but rare in 6 species of birds' feces. It was worth to point out that the $16 \mathrm{~S}$ rDNA sequence similarities of 13 of 207 sequenced strains with valid published species were below $98.5 \%$. In other words, about $6 \%$ pure cultivated strains were un-known, and were possible novel species [10-11].

These results indicated that, first, members of three genera Streptomyces, Rhodococcus and Arthrobacter were the widest distribution in a largest amount in bird feces; second, composition of actinobacteria with Chemotype IV to IX [12-13] and globose or bacilliform shapes, specially order Micrococcales, were the richest diversity, and occurred a high frequency in most part of tested bird feces. These are distinct features of cultivable fecal actinomecete community differing from those in soil, oceans, water environment and plant.

\subsection{Bioactivites of the Isolates}

The antimicrobial activities of 91 purified strains were determined, and key genes related the synthesis of 3 groups of compounds: CYP, AHBA, SAL, were screened in 91 purified strains genome DNA. The results were shown in Table 4.

Table 4. Number of positive strains with antimicrobial activities and three genes from 3 bird fecal strains.

\begin{tabular}{llll}
\hline Bioactivities and Genes & Pavo cristatus & Grus japonensis & Larus ridibundus \\
\hline Number of test strains & 30 & 25 & 36 \\
Antimicrobial activities: & 1 & & 2 \\
Bacillus subtills & 2 & 2 & 7 \\
Pseudomonas aeruginosa & 2 & 1 & 13 \\
Monilia albican & 1 & 2 & 3 \\
Escherichia coli & 2 & 4 & 1 \\
Bacillus subtilis & 0 & 0 & 0 \\
Fungus pathogen* 10090501 & 3 & 2 & 4 \\
Fungus pathogen 10090502 & 2 & 2 & 3 \\
Fungus pathogen 10090504 & 1 & 5 & 6 \\
Fungus pathogen 10090506 & 1 & 0 & 5 \\
Fungus pathogen 100914-2 & $5.0 \%$ & $8.0 \%$ & $12.2 \%$ \\
Average of positive strains (\%) & & & 14 \\
Biosynthase genes: & 6 & 6 & 11 \\
CYP & 5 & 0 & 19 \\
AHBA & 9 & 0 & $40.8 \%$ \\
SAL & $22.2 \%$ & $8.0 \%$ & \\
Average of positive strains (\%) & & & \\
\hline
\end{tabular}

*=un-identified pathogens of Yunnan pseudo-ginseng

As depicted from Table 4 that fecal actinobacteria from Pavo cristatus, Grus japonensis and Larus ridibundus had average $5.0 \%, 8.0 \%$ and $12.2 \%$ respectively antimicrobial activities against 10 tested bacteria and fungi. These results demonstrated that actinobacteria from bird feces have wide and universal anti-microbial activities, and the activities of some strains were high.

Polyene antibiotics, including a large of number of antibiotics, such as nystatin, amphotericin, pimaricin, and candicidin etc., were produced principally by soil actinobacteria, have wide antifungal activities [7, 14]. Ansa antibiotics had very high activities to cancers. The biosynthase genes encoding these typical compounds have been cloned [8]. It is discovered recently that antitumor activity of salinomycin, an old antibiotic, was higher than taxol for 100 times [15]. Finding the similar compounds 
and their producers of three typical antibiotics were useful. The 3 genes in 91 strains were detected (Table 4). In 30, 25, and 36 actinobacteria strains which isolated from Pavo cristatus, Grus japonensis and Larus ridibundus feces respectively, average $22.2 \%, 8.9 \%$ and $40.8 \%$ strains had the three genes strips. These strains having three synthase genes included members of Streptomyces (12 strains), Rhodococcus, Arthrobacter and Oerskovia. The most of them were isolated from fecal samples collected from Larus ridibundus. It needs to direct that actinobacteria from bird feces had not only high antimicrobial activities, but contained the 3 biosynthase genes in a very high frequency. Maybe this is extraordinary.

Those strains possessing these qualities at the same time: possible novel species, having antimicrobial activities and useful genes, fast growth, and easy to culture, will be selected as the candidate of study future for discovery of leading compounds of new drugs.

\subsection{Secondary Compounds with Bioactivities}

More than 30 bioactive secondary metabolites from several actinomycete strains of bird feces were isolated and characterized. Actinomycte strain YIM 100961 from Larus ridibundus feces produced Erythronolide (analogues with formulas such as $\mathrm{C} 21 \mathrm{H} 32 \mathrm{O} 6, \mathrm{C} 21 \mathrm{H} 34 \mathrm{O} 6, \mathrm{C} 20 \mathrm{H} 32 \mathrm{O} 7$, C20H34O7, C21H34O7, C21H36O7), Erythromycins (analogues C30H51NO10, C31H53NO10, C32H55NO10, C33H57NO10), Spinosyn (C44H77NO13, C45H79NO13) and Leuconolide analogues $(\mathrm{C} 20 \mathrm{H} 32 \mathrm{O} 7, \mathrm{C} 21 \mathrm{H} 34 \mathrm{O} 7)$, total 19 compounds. Strain YIM 100790 from Larus ridibundus feces produced Kidamycin, Erythromycins, Actinomycin and high level of unknown polyketide. Desertomycin, Oasomycins and a large numbers of un-known polyketides and compounds with C59H78O19, C47H76O19, C57H102NO24, C62H90N3O19 have been isolated and characterized from other strains of bird feces. It is indicate that these compounds from actinomycetes of bird feces have diverse and complex structure and various activities. Structures and activities of some novel compounds of them are studied.

\section{Discussion and Conclusions}

Development of new drug from Actinobacteria is increasingly difficulty because massive bioactive metabolites from the actinomycetes were found and studied. Finding novel leads from un-known actinomycetes in special habitats is one of new hope. Up to now, the research works on animal fecal actinobacteria, as a type of a source for developing novel drugs, were still few. Study on bird fecal actinobacteria was not found in science literatures. Results of this study indicated that diversity of bird fecal actinobacteria was not only very complex comparing with the diversities of actinobacteria in soils, oceans, plants and extreme environments, but difference each other; the bioactivities of bird fecal actinobacteria were also wide and high, and biosynthase genes of some antibiotics were existed widely. More than 30 bioactive secondary metabolites from several actinomycete strains of bird feces were isolated and characterized. Streptomyces and Rhodococcus were the predominant genera and the widest distribution in bird feces. Genome sizes of this two genera are up to $9 \times 10^{7}$ base pairs, one of biggest genome in actinbacteria, and some species of them contained 20 or more natural product biosynthetic gene clusters [16-18]. So we showed further a assumption that first, the function of actinobacteria in intestinal tract of hosts was played mainly role going through bioactive substances produced by members of the two genera; Second, secondary metabolites with bioactivities produced by fecal actinobacteria except pathogen, should be no toxic or lower toxic to their hosts. Maybe these are very important excellence comparing with the metabolites from other microorganisms from other habitats. Therefore, animal fecal actinobacteria are one of important and new resources for developing novel antibiotics, anti-tumor agents, enzyme inhibitors, immunity inhibitor, agricultural chemicals, enzymes and other useful products. Related research works should be strengthened in the future.

Some actinobacteria were the pathogen of human and animal [19]. Like Cellulosimicrobium funkei, first discovered in the clinical, was an opportunistic pathogen, close to Oerskovia in taxonomy and mainly infected people who have immune dysfunction or inflammation [20-21], was found in this study, too. Therefore the fresh fecal samples have to be collected from health bodies. The whole research work should be carried out under strict sterile conditions for avoiding pathogens to interference researchers.

\section{Acknowledgements}

This research was supported by the National Natural Science Foundation of China (no. 31270001 and no. 81072553), National Major scientific and technology special projects (2009ZX09302-003), National Institutes of Health USA (1P 41GM 086184-01A 1).

\section{References}

[1] Berdy J, Thoughts and facts about antibiotics: Where we are now and where we are heading. J Antibiot, 2012; 65(8): 385-395.

[2] Cao YR, Jiang Y, Li YL, Chen X, Jin RX, and He WX, Isolation methods and diversity of culturable fecal actinobacteria associated with Panthera tigris tigris in Yunnan Safari Park. Acta Microbiologica Sinica, 2012; 52(7): $816-824$.

[3] Jiang Y, Cao YR, Han L, Jin RX, Zheng D, He WX, Li YL, and Huang XS, Diversity and bioactivity of culturable actinobacteria from 5 species of animal feces. Acta Microbiologica Sinica, 2012; 52(10): 1282 - 1289.

[4] Hayakawa M, and Nonomura H, Humic acid-vitamin agar, a new medium for the selective isolation of soil actinobacterias. J Ferment Technol, 1987; 65: 501-509. 
[5] Cui XL, Mao PH, Zeng M, Xu LH, and Jiang CL, Streptomonospora salina gen. nov., sp. nov., a new member of the family Nocardiopsaceae. Int. J. Syst. Evol. Microbiol, 2001; 51: 357- 363 .

[6] Kim OS, Cho YJ, Lee K, Yoon SH, Kim M, Na H, Park SC, Jeon YS, Lee JH, Yi H, Won S, and Chun J, Introducing EzTaxon-e: a prokaryotic $16 \mathrm{~S}$ rRNA gene sequence database with phylotypes that represent uncultured species. Int J Syst Evol Microbiol, 2012; 62: 716-721.

[7] Kim BG, Lee MJ, Seo J, Hwang YB, Lee MY, Han K, Sherman DH, and Kim ES Identification of functionally clustered nystatin-like biosynthetic genes in a rare actinobacterias, Pseudonocardia autotrophica. J Ind Microbiol Biotechnol, 2009; 36(11):1425-1434.

[8] Kim CG, Yu TW, Fryhle CB, Handa S, and Floss HG, 3-Amino-5-hydroxybenzoic acid synthase, the terminal enzyme in the formation of the precursor of $m C 7 \mathrm{~N}$ units in rifamycin and related antibiotics. J Biol Chem 273, 1998; (11): 6030-6040.

[9] Knirschová R, Nováková R, Fecková L, Timko J, Turna J, Bistáková $\mathrm{J}$, and Kormanec $\mathrm{J}$, Multiple regulatory genes in the salinomycin biosynthetic gene cluster of Streptomyces albus CCM 4719. Folia Microbiol (Praha), 2007; 52(4): $359-65$.

[10] Stackebrandt E, and Goebel BM, Taxonomic note: a place for DNA-DNA reassociation and 16s rRNA sequence analysis in the present species definition in bacteriology. Int J Syst Evol Microbiol, 1994; 44(4): 846-849.

[11] $\mathrm{Xu} \mathrm{LH,} \mathrm{Li} \mathrm{WJ,} \mathrm{Liu} \mathrm{ZH,} \mathrm{and} \mathrm{Jiang} \mathrm{CL,} \mathrm{Actinobacteria}$ taxonomy. Acedemic Press, Beijing, 2007.

[12] Lechevalier MP, and Lechevalier HA, Chemical composition as a criterion in the classification of aerobic actinobacterias. Int J Syst Bacteriol, 1970: 20: 435-443.

[13] Lechevalier MP, and Lechevalier HA, The chemotaxonomy of actinobacterias. In A. Dietz and D.W. Thayer (eds.), Actinobacteria taxonomy. Special publications No. 6. Society for Industrial Microbiology, Arlington, USA, 1980; 227- 291.

[14] Lee MY, Myeong JS, Park HJ, Han K, and Kim ES, Isolation and partial characterization of a cryptic polyene gene cluster in Pseudonocardia autotrophica. J Ind Microbiol Biotechnol, 2006; 33(2): 84-87.
[15] Gupta PB, Onder TT, Jiang GZ, Tao K, Kuperwasser C, Weinberg RA, and Lander ES, Identification of selective inhibitors of cancer stem cells by high-throughput screening. Cell, 2009: 138(4): 1-15.

[16] Bentley SD, Chater KF, Cerdeno-Tarraga AM, Challis GL, Thomson NR, James KD, Harris DE, Quail MA, Kieser H, Harper D, Bateman A, Brown S, Chandra G, Chen CW, Collins M, Cronin A, Fraser A, Goble A, Hidalgo J, Hornsby $\mathrm{T}$, Howarth S, Huang CH, Kieser T, Larke L, Murphy L, Oliver K, O’Neil S, Rabbinowitsch E, Rajandream MA, Rutherford K, Rutter S, Seeger K, Saunders D, Sharp S, Squares R, Squares S, Taylor K, Warren T, Wietzorrek A, Woodward J, Barrell BG, Parkhill J, and Hopwood D, Complete genome sequence of the model actinomycete Streptomyces coelicolor A3(2). Nature 417, 2002; 6885:141-147.

[17] McLeod MP, Warren RL, Hsiao WL, Araki N, Myhre M, Fernandes C, Miyazawa D, Wong W, Lillquist AL, Wang D, Dosanjh M, Hara H, Petrescu A, Morin RD, Yang G, Stott JM, Schein JE, Shin H, Smailus D, Siddiqui AS, Marra MA, Jones SJ, Holt R, Brinkman FS, Miyauchi K, Fukuda M, Davies JE, Mohn WW, and Eltis LD, The complete genome of Rhodococcus sp. RHAl provides insights into a catabolic powerhouse. Proc Natl Acad Sci U S A, 2006; 103(42): 15582-15587.

[18] Omura S, Ikeda H, Ishikawa J, Hanamoto A, Takahashi C, Shinose M, Takahashi Y, Horikawa H, Nakazawa H, Osonoe T, Kikuchi H, Shibai T, Sakaki Y, and Hattori M, Genome sequence of an industrial microorganism Streptomyces avermitilis: Deducing the ability ofproducing secondary metabolites. Proc Natl Acad Sci USA , 2001; 98(21): 12215-12220.

[19] Beman BL, Actinomycete pathogen. In Goodfellow M, Mordarski M. and Williams S.T.(eds.). The biology of the actinomyces. Academic press, London, UK, 1983; 457-480.

[20] Brown JM, Steigerwalt AG, Morey RE, Daneshvar MI, Romero LJ, and McNeil MM, Characterization of clinical isolates previously identified as Oerskovia turbata: proposal of Cellulosimicrobium funkei sp. nov. and emended description of the genus Cellulosimicrobium. Int J Syst Evol Microbiol, 2006; 56: 801-804.

[21] Petkar H, Li A, Bunce N, Duffy K, Malnick H, and Shah JJ, Cellulosimicrobium funkei: first report of infection in a nonimmunocompromised patient and useful phenotypic tests for fferentiation from Cellulosimicrobium cellulans and Cellulosimicrobium terreum. J Clin Microbiol, 2011; 49(3): $1175-8$. 